\title{
Prediction Models for Water Erosion Risk Management: A Review
}

\author{
*1AHAMEFULE, HE; ${ }^{1}$ FATOLA, FO; ${ }^{1}$ OLANIYAN, JO; ${ }^{2}$ AMANA, MS; ${ }^{1}$ EIFEDIYI, \\ EK;; ${ }^{3}$ IHEM, E; ${ }^{4}$ NWOKOCHA, CC; ${ }^{1}$ ADEPOJU, AS; ${ }^{1}$ ADEPOJU, IO; ${ }^{1}$ BABALOLA, \\ MJ \\ ${ }^{1}$ Department of Agronomy, University of Ilorin, P.M.B.1515, Ilorin, Kwara State, Nigeria. \\ ${ }^{2}$ Department of Soil Science, Nasarawa state University, Lafia, Nigeria. \\ ${ }^{3}$ Department of Soil Science and Technology, Federal University of Technology Owerri, Imo State, \\ Nigeria. \\ ${ }^{4}$ National Root Crops Research Institute, Umudike, Abia State, Nigeria. \\ *Corresponding Author Email: flamepearls@yahoo.com; ahamefule.he@unilorin.edu.ng; Tel: +2348037763570,+23470106143
}

\begin{abstract}
In order to estimate the potential soil erosion hazard of an area, erosion prediction models are needed. Various models have been used by researchers, which ranges from mathematical and conceptual simple approaches to complex models that try to include the complexities of the real world. Six (6) models are reviewed in relation to their suitability for use. The KINEROS, CORINE and EUROSEM were best suited for water erosion risk prediction in cultivated soils. On the other hand, the KINEROS, PESERA, CORINE and EUROSEM were found to be applicable in all sectors (Agronomy, water resources management and road construction) highlighted. The GLASOD had the least applicability with respect to this study.
\end{abstract}

\section{DOI: https://dx.doi.org/10.4314/jasem.v22i9.05}

Copyright: Copyright (C) 2018 Ahamefule et al. This is an open access article distributed under the Creative Commons Attribution License (CCL), which permits unrestricted use, distribution, and reproduction in any medium, provided the original work is properly cited.

Dates: Received: 13 December 2017; Revised: 12 August: 2018; Accepted: 09 September 2018

Keywords: Water Erosion, sediment transport models, Model structure and suitability for use

Soil erosion by water has been a major environmental threat to the sustainability and productivity of agriculture, available data suggests that arable land is lost at a rate of more than 10 million ha per year (Pimentel et al, 1995). Information on soil erosion and its effects on water and land resources on plot or catchment scales are increasingly sought by land resource managers and stakeholders. This has led to continuous researches which focus on soil erosion processes as well as its modelling (Merritt et al., 2003). Majority of the Water Erosion Risk Prediction Models (WERPM) that were earlier developed to provide information on erosion and water quality processes are inappropriate for providing catchment scale, eventbased predictions of sediment loads. They have shortcomings which includes over-parameterization, unrealistic input requirements, unsuitability of model assumptions, and inadequate documentation of model testing and resultant performance (Merritt et al., 2003). Development in the use of computer programming over time has led to rapid increase in the estimation of erosion soil loss, transport and sediment through the use of computer models.

These models have differences such as complexity, the kind of processes considered, and the data required for measurement. There is no perfect model for all applications; rather, the model to be used will depend on the intended use and the characteristics of the area of focus. In general, models fall into three main categories: Empirical or statistical, conceptual and physics based models. The categorization of models depends on the physical processes simulated by the model, the model algorithms describing these processes and the data dependence of the model.

This paper is essentially, a simplified review of soil erosion risk prediction models majorly drawn from the work of Merit et al. (2003) with an infusion of other models not covered in their review. There are many models available but more often than not, their strengths and weaknesses are unknown. Therefore, the aim of this paper is to showcase and compare the characteristics of the current water erosion prediction models available in literature.

\section{MATERIALS AND METHODS}

Models that have been covered in the review of Merit et al. (2003) shall be firstly, briefly highlighted whereas those not included like the Kinematic Runoff and Erosion Model (KINEROS), the Integrated Catchments Model (INCA), the Pan-European Soil Erosion Risk Assessment model (The PESERA model), the Coordination Information Environment

*Corresponding Author Email: flamepearls@yahoo.com; ahamefule.he@unilorin.edu.ng; Tel: 
Model (The CORINE), the European Soil Erosion Model (EUROSEM) and the Global Assessment of Soil Degradation (GLASOD) shall be reviewed under: model outputs, input data, model structure and predictive accuracy/ limitations where known. Their suitability for use shall thereafter be determined.

Empirical or Statistical Models: Empirical models are the simplest of all the types of model. They are based on observations of the environment and thus, are often of statistical relevance (Nearing et al., 1994). Empirical models are frequently used in modelling complex processes in erosion, especially in identifying the sources of sediments (Merit et al., 2003). Empirical models are often criticised for employing unrealistic assumptions about the physics of the catchment system, ignoring the heterogeneity of catchment inputs and characteristics, such as rainfall and soil types (Wheater et al., 1993). Nonetheless, empirical models are frequently used in preference to more complex models as they can be adopted in situations with limited data and parameter inputs, and are particularly useful as a first step in identifying sources of sediment and nutrient generation (Prosser $e t$ al., 2001a).

Universal Soil Loss Equation and Modifications: The Universal Soil Loss Equation (USLE) is a soil erosion model used globally. This model was synthesized by the United States Department of Agriculture (USDA) in the 1970s, to this point; the model has undergone much tests and a number of modifications (Merit et al., 2003). The model has also been upgraded to take into account additional information that has become available since its development (Renard et al., 1994).

Identification of unit Hydrographs and Component flows from Rainfall, Evaporation and Streamflow (IHACRES-WQ): The IHACRES (Identification of unit Hydrographs and Component flows from Rainfall, Evaporation and Streamflow data) model was developed by Jakeman and Hornberger (1993). The module can be used to simulate streamflow (catchment runoff) on the basis of daily rainfall and temperature data. No spatial data, such as elevation models, soil or land use maps are required. It (IHACRES) has been applied to catchments with a wide range of climatologies and sizes (Croke and Jakeman, 2001). It has been used to predict streamflow in ungauged catchments (Post and Jakeman, 1999), to study land cover effects on hydrologic processes (Croke et al., 2004).

The Sediment River Network (SedNet): The Sediment River Network (SedNet) model is a steady-state model that was developed for estimating sediment generation and deposition from hill slopes, gullies and riverbanks in a river network (Prosser et al., 2001b). The SedNet was developed as a tool for addressing land and water management issues at the catchment or larger scale.

Conceptual Models: Conceptual models are a mixture of empirical and physically based models, thus more applicable to answer general questions (Beck, 1987). These models usually incorporate general descriptions of catchment processes without specifying process interactions that would require very detailed catchment information (Merit et al., 2003). Parameter values for conceptual models have typically been obtained through calibration against observed data, such as stream discharge and concentration measurements (Abbott et al., 1986). Due to the requirement that parameter values are determined through calibration against observed data, conceptual models tend to suffer from problems associated with the identifiability of their parameter values (Jakeman and Hornberger, 1993).

Environmental Management Support System (EMSS): The Environmental Management Support System (EMSS) is a software tool (as opposed to a model) developed to aid water quality management in catchments and waterways in the South-east Queensland region of Australia. The system is being developed in the Cooperative Research Centre for Catchment Hydrology (CRCCH) and is implemented in the Tarsier modelling framework (Watson et al., 2001). At present, the EMSS is composed of three models: a lumped conceptual rainfall- runoff and pollutant export model ('Colobus'), a flow and pollutant routing model ('Marmoset') and a storage model referred to as 'Mandrill' (Vertessey et al., 2001).

Hydrologic Simulation Programme Fortran (HSPF): The Hydrologic Simulation Programme Fortran (HSPF) was developed based on the 1960s Stanford Watershed Model, for the simulation of watershed hydrology and water quality (nitrogen, phosphorus, suspended sediment and other toxic organic or inorganic pollutants) (Walton and Hunter, 1996).

The model is a catchment scale, conceptual model whereby catchments are divided into hydrologically homogeneous land segments. Water quantity and quality is calculated for each land use in a land segment. Water, sediment and chemical fluxes are then added to the stream, and these fluxes are routed to the catchment outlet. The model consists of three main modules: the pervious land module, the impervious land module, and the river/mixed reservoir module.

AHAMEFULE, HE; FATOLA, FO; OLANIYAN, JO; AMANA, MS; EIFEDIYI, EK; IHEM, E; NWOKOCHA, $C C$; ADEPOJU, AS; ADEPOJU, IO; BABALOLA, MJ 
Integrated Water Quantity and Quality Model (IWQQM): The Integrated Water Quantity and Quality Model (IWQQM) is a largely conceptual model developed by the Department of Land and Water Conservation in Australia. The model is designed for use as a tool for planning and evaluating water resource management policies at the river basin scale (DLWC, 1999). The IWQQM has modules for instream water quality and quantity as well as for rainfall-runoff and groundwater quantity (Simons et al., 1996).

Large Scale Catchment Model (LASCAM): The LASCAM (Large Scale Catchment Model) is a salt and water balance model and has been adapted to include a sediment generation and transport algorithm for modelling hydrological processes at a catchment scale (Viney and Sivapalan, 1999). The model is capable of predicting long-term estimates of daily stream loads of water, salt, sediment and nutrients (Merit et al., 2003).

Simulator for Water Resources in Rural Basins (SWRRB): The Simulator for Water Resources in Rural Basins (Arnold et al., 1990) was developed to simulate hydrologic, sedimentation, and nutrient and pesticide transport in large complex rural watersheds. The model incorporates five major components: climate, hydrology, sediment, nutrients and pesticides. The models in these modules borrow to a large extent from existing models. The SWRRB-WQ is an extension of SWRRB that includes water quality components (Arnold et al., 1991).

Physics Based Models: Physics based models represent natural processes by describing each individual physical process of the system and combining them into a complex model. Physical equations hereby describe natural processes, such as stream flow or sediment transport (Merit et al., 2003). Physics based models are able to explain the spatial variability of most important land surface characteristics such as topography, slope, aspect, vegetation, soil, as well as climate parameters including precipitation, temperature and evaporation (Legesse et al., 2003).

Chemical Runoff and Erosion from Agricultural Management Systems (CREAMS): The Chemical Runoff and Erosion from Agricultural Management Systems model (Knisel, 1980) was developed as a tool to evaluate the relative effects of agricultural practices on pollutants in surface runoff and in soil water below the root zone (Knisel, 1980; Lane et al., 1992; Lane et $a l .$, 1995). There has been extension and modification of CREAMS in GLEAMS- the Groundwater Loading
Effects of Agricultural Management Systems (Ball and Trudgill, 1995; Connolly et al., 1999).

Watershed Erosion Prediction Project (WEPP): The Watershed Erosion Prediction Project (WEPP) is a physics-based model developed in the United States (Laflen et al., 1991; NSERL, 1995). The model has been applied to hill slopes widely in the US (Laflen et al., 1991) and worldwide. The model was intended to determine and/or assess the essential mechanisms controlling erosion by water, including anthropogenic impacts. The model does not consider erosion, transport and deposition processes in permanent channels, such as classical gullies and perennial streams. A watershed version of the model has been developed and applies to field areas that include ephemeral gullies which can be farmed over and links these surface erosion processes to the channel network.

Areal Nonpoint Source Watershed Environment Response Simulation (ANSWERS: The ANSWERS program (Beasley et al., 1980) creates a common basis for the structure of process-based hydrologic and water quality models (Moore and Gallant, 1991).

Griffith University Erosion System Template $($ GUEST): The GUEST is a steady-state, processbased model developed to interpret temporal fluctuations in sediment concentration from bare soil in single erosion events (Misra and Rose, 1996). The model relates measured runoff and rainfall rates, soil characteristics and plot geometry of uniform slope to the concentration of eroded sediment. The model is based on the work of Hairsine and Rose (1991) and Rose (1993).

Limburg Soil Erosion Model (LISEM): The Limburg Soil Erosion Model (De Roo and Jetten, 1999) is a spatially distributed, physics-based hydrological and soil erosion model, developed by the Department of Physical Geography at Utrecht University and the Soil Physics Division at the Winard Staring Centre in Wageningen, the Netherlands, for planning and conservation purposes. The LISEM model is based on EUROSEM (Morgan et al., 1998). The LISEM incorporates a number of different processes including rainfall interception, surface storage in microdepressions, infiltration, vertical water movement through the soil, overland flow, channel flow, detachment by rainfall and through-fall, detachment by overland flow and transport capacity of flow.

MIKE-11: The MIKE-11 is a computer programme used for water quality modelling, developed by the Danish Hydrologic Institute (DHI). The model is a

AHAMEFULE, HE; FATOLA, FO; OLANIYAN, JO; AMANA, MS; EIFEDIYI, EK; IHEM, E; NWOKOCHA, $C C$; ADEPOJU, AS; ADEPOJU, IO; BABALOLA, MJ 
one-dimensional (cross-sectional averaged) dynamic model consisting of a number of modules (Hanley et al., 1998). The basic modules are a rainfall-runoff component, a hydrodynamic module, a water quality module, and a sediment transport module.

Productivity Erosion and Runoff Functions to Evaluate Conservation Techniques (PERFECT): The Productivity, Erosion and Runoff, Functions to Evaluate Conservation Techniques (PERFECT) model was developed in Australia (Littleboy et al., 1992b). The model was developed in response to the limited applicability of models, such as CREAMS, for analysing the effects of soil management practices, such as tillage or fallow management strategies (Littleboy et al., 1996). Models such as CREAMS calculate runoff as a function of rainfall and soil water content, excluding surface and crop cover changes resulting from tillage practices. The PERFECT model was designed to predict runoff, erosion and crop yield for some management options in dry land cropping areas of Australia, including sequences of plantings, harvests and stubble management during fallow (Littleboy et al., 1996). The model is comprised of six modules: data input, water balance, crop growth, crop residue, erosion and model output. The modules draw on other models such as MUSLE and CREAMS.

TOPOG: The TOPOG was initially developed as a physics-based, catchment scale hydrological model that linked three dimensional terrain attributes with a simple description of water movement (O'Loughlin, 1986). The programme has received on-going attention and now is a package that can be used to simulate water, carbon, solutes and the sediment balance of catchments.

The KINEROS model: The kinematic runoff and erosion model KINEROS Gavrilovic (1972) is an event oriented, physically based model describing the processes of interception, infiltration, surface runoff and erosion from small agricultural and urban watersheds. The watershed is represented by a cascade of planes and channels; the partial differential equations describing overland flow, channel flow, erosion and sediment transport are solved by finite difference techniques. The spatial variation of rainfall, infiltration, runoff, and erosion parameters can be accommodated. The KINEROS model may be used to determine the effects of various man-made structures such as urban infrastructures, small detention reservoirs, or lined channels on flood hydrographs and sediment output.

Model outputs: The model calculates rainfall infiltration rates and sediments.
Input data: Data required are the rainfall and runoff amount.

Model structure: The KINEROS uses onedimensional kinematic equations to simulate flow over rectangular planes and through trapezoidal open channels, circular conduits and small detention ponds. KINEROS is a distributed model. Multi-gage rainfall input is distributed by assigning rain gages to overland flow planes. The infiltration algorithm is dynamic, interacting with both rainfall and surface water in transit

The INCA model: The Integrated Catchments model is a generic, catchment-scale biogeochemical modelling framework. INCA is semi-distributed and operates on a daily time step

Model outputs: INCA model have been developed to simulate nitrogen dynamics (Whitehead et al., 1998; Wade et al. 2002a), phosphorus (Wade et al., 2002b), organic carbon and suspended sediments (Futter et al., 2007).

Input data: INCA model computer program requires few data which includes estimates of catchment area, land cover, soil size classes and mean stream slope are required to run the model. Information on vegetation cover and length of growing season is also required to reduce errors in the model predictions. The model requires daily time series of temperature and precipitation. Time series of stream flow and solute concentrations (e.g. DOC, suspended sediments) are used in model calibration.

Model structure: The INCA modelling system runs under the MS-Windows environment on compatible computers. The modelling system is designed with a user-friendly graphical interface, a data management system and a fourth-order Runge Kutta differential equation solver. The environmental processes in INCA model are represented as a set of linked first order differential equations. The INCA model operates on a daily time step.

The PESERA model: The Pan-European Soil Erosion Risk Assessment model (PESERA) is used to predict hill slope erosion and the transportation of sediment down slope. It is useful for different range of scales such as regional catchments to national and international scales (Kirkby et al., 2004). The model is physically-based whereby the data are synthesized for the purpose of estimating the quantity and frequency of saturated overland flow in a grid cell by the application of a simple soil moisture storage model.

AHAMEFULE, HE; FATOLA, FO; OLANIYAN, JO; AMANA, MS; EIFEDIYI, EK; IHEM, E; NWOKOCHA, $C C$; ADEPOJU, AS; ADEPOJU, IO; BABALOLA, MJ 
Model outputs: The model output is monthly sediment yields per grid cell (tonnes/ha) and its application within a Geographic Information System means that the model is spatially distributed.

Input data: The datasets needed in the PESERA model include climate data (monthly average rainfall, potential evapo-transpiration and temperatures), soil data (texture and available water capacities), land cover including crop type where appropriate, and topography.

Model structure: The model uses a frequency distribution of rainfall events to estimate the long-term averages for each month, then added together to give annual totals. The erodibility of soil particles is determined from soil texture and combined with the runoff calculated from the storage model, the steepness of the slope and the slope length to estimate sediment losses.

Predictive accuracy/limitations: The model is best suitable for European soils

The CORINE model: The (Coordination Information Environment) programme is the continuation of the previous programme "Ecological Cartography of the European Community" (1977). Its main aim is to collect, manage the environmental data to be utilized primarily for the prediction of relevant environmental problems such as biotopes acid rains, atmospheric pollution, water pollution, soil erosion and land quality in the European Community. It involves the collection of basic information on land quality and soil erosion risk. The Data collected were interpreted according to appropriate guidelines and submitted to an international steering group.

Integration of the data into an information system which will help analyze and map land quality and soil erosion at a scale feasible for actions. Evaluation and validation of methodologies and results in order to define future needs for research and to develop, extend and ameliorate the present land quality and soil erosion risk assessment.

After which the results which are in form of maps were validated and then transmitted to the GIS working group for digitization and integration into the CORINE database.

Model outputs: The model output is monthly sediment yields per grid cell (tonnes/ha) and its application within a Geographic Information System means that the model is spatially distributed.
Input data: The model works on the basis of the Universal Soil Loss Equation Factors which includes; rainfall erosivity, soil erodibility, topography conditions, vegetation cover and management practices.

Model structure: The model involves the computation of four basic indices, which are:

(i) Soil quality (assessed on the basis of soil texture, depth, drainage status);

(ii) Climate quality (calculated from the BagnoulsGaussen aridity index, the length of the vegetative period and the frost risk);

(iii) Topography (indicated by slope angle); and

(iv) Infrastructural improvements (the presence of permanent irrigation, drainage or terracing);

Predictive accuracy/limitations: The availability of basic data in the European Community (and especially in the southern regions) was often very limited. Lack of consistent data has therefore limited the quality of the final results obtained.

The EUROSEM model: was developed as a distributed event-based model that, in addition to predicting total runoff and soil loss, produces hydrographs and sediment graphs for each event (Morgan et al., 1998).

Model outputs: The output is the sediment transport and deposition rates.

Input data: Input data includes rainfall data, runoff and vegetation cover.

Model structure: It is made up of a modular structure, which includes:

The interception of rainfall by the plant covers 2 . The volume and kinetic energy of the rainfall reaching the ground surface as direct through-fall and leaf drainage 3 . The volume of stream flow 4 . The volume of surface depression storage 5 . The detachment of soil particles by raindrop impact and by runoff 6 . Sediment deposition 7. The transport capacity of the runoff. Algorithms also deal with frozen soils and stoniness.

Predictive accuracy/limitations: The availability of basic data in the European Community (and especially in the southern regions) was often very limited. Lack of consistent data has therefore limited the quality of the final results obtained.

The GLASOD approach: The GLASOD model was made to map the severity of degradation on a world scale, as the World map of the statue of humaninduced soil degradation (Oldeman et al., 1991). The aim of the model is:

AHAMEFULE, HE; FATOLA, FO; OLANIYAN, JO; AMANA, MS; EIFEDIYI, EK; IHEM, E; NWOKOCHA, CC; ADEPOJU, AS; ADEPOJU, IO; BABALOLA, MJ 
To take the GLASOD classification of types of degradation as the basis for development.

To adopt the GLASOD definitions for degrees of severity of degradation.

To treat the GLASOD assessments of the extent of degradation as a starting point or standard against which other estimates can be compared; but not necessarily to adopt them as the best estimates where evidence suggests otherwise.

Model Structure: The model is structured as forms of the degrees of degradation, which are:

Light: somewhat reduced agricultural productivity. Moderate: greatly reduced agricultural productivity. Strong: irreclaimable at farm level.

Extreme: irreclaimable and impossible to restore (with present technology).

Model outputs: The output is a map showing different degree severity of degradation of a particular area.

Input data: Data such as background information (physiography, soils, geology, climate, population, land use, vegetation); area of the map unit (square kilometres); a list of all types of land degradation identified, giving for each type, degree (severity), extent (as percentage of the map unit affected), present rate, and principal causes and remarks on each type and on the unit as a whole are needed for mapping degradation in the GLASOD model.

Predictive accuracy/limitations: It has been used majorly in the Asian continent (F.A.O, 1994). Its applicability in other continents has not been tested.

\section{RESULTS AND DISCUSION}

The result show that the KINEROS, CORINE and EUROSEM are the best in terms of the number of water erosion associated problems it can be used to predict (Table 1). Soil loss is preponderant in poorly managed cultivated land due to tillage disturbances, this occur under sheet and rill erosion. Therefore, among the six (6) models under review, KINEROS, CORINE and EUROSEM models are best suited for water erosion risk prediction in cultivated soils.

All the models reviewed is suited for agronomic purposes (Table 2), however it should be noted that while KINEROS, CORINE and EUROSEM are specifically suited for water erosion risk prediction in fields under agronomic practices, INCA, PESERA and GLASOD is more suited for soil degradation arising from soil nutrient loss under same conditions. Soil and/ or nutrient loss may occur in the water erosion process. Furthermore, the KINEROS, PESERA, CORINE and EUROSEM were found to be applicable in all sectors (agronomy, water resources management and road construction) highlighted. The GLASOD only applied in agronomy and therefore had the least applicability with respect to this study.

Table 1: Evaluation of various WERPM based on ability to solve

\begin{tabular}{llll}
\multicolumn{4}{c}{ some erosion problems } \\
\hline Model & $\begin{array}{l}\text { Sheet } \\
\text { erosion }\end{array}$ & $\begin{array}{l}\text { Rill } \\
\text { erosion }\end{array}$ & $\begin{array}{l}\text { Soil } \\
\text { loss }\end{array}$ \\
\hline KINEROS & + & + & + \\
INCA & - & - & + \\
PESERA & - & + & + \\
CORINE & + & + & + \\
EUROSEM & + & + & + \\
GLASOD & - & - & - \\
\hline
\end{tabular}

Table 2: Evaluation of WERPM based on applicability to selected

\begin{tabular}{llll}
\hline \multicolumn{3}{c}{ sectors } \\
& Agronomy & $\begin{array}{l}\text { Water resources } \\
\text { management }\end{array}$ & $\begin{array}{l}\text { Road } \\
\text { constructio } \\
\mathrm{n}\end{array}$ \\
\hline KINEROS & + & + & + \\
INCA & + & + & - \\
PESERA & + & + & + \\
CORINE & + & + & + \\
EUROSEM & + & + & + \\
GLASOD & + & - & - \\
\hline
\end{tabular}

Conclusion: Among six (6) models reviewed, the KINEROS, CORINE and EUROSEM are best suited for water erosion risk prediction in cultivated soils. On the other hand, the KINEROS, PESERA, CORINE and EUROSEM were found to be applicable in all sectors (agronomy, water resources management and road construction) highlighted. The GLASOD had the least applicability (agronomy) with respect to this study.

\section{REFERENCES}

Abbott, M.B., Bathurst, J.C., Cunge, J.A., O'Connell, P.E., Rasmussen, J. (1986). An introduction to the European Hydrological System- Systeme Hydrologique Europeen, SHE. 1. History and philosophy of a physically-based, distributed modelling system. Journal of Hydrology 87: 45-59.

Arnold, J.G., Williams, J.R., Griggs, R.H., Sammons, N.B. (1990). SWRRB-a basin scale simulation model for soil and water resources management. A\&M Press, Texas.

Arnold, J.G., Williams, J.R., Griggs, R.H., Sammons, N.B. (1991). SWRRBWQ-a basin model for assessing management impacts on water quality. USDA,ARS, Grassland, Soil, and Water Research Laboratory, Temple, TX.

Ball, J., Trudgill, S.T. (1995). Overview of solute modelling. In: Trudgill, S.T. (Ed.), Solute Modelling in Catchment Systems. John Wiley and Sons, England, pp. 3 - 56 . 
Beasley, D.B., Huggins,L.F, Monke, E.J. (1980). ANSWERS- a model for watershed planning. Trans. Am. Soc. Agric. Eng.23: 938 - 944.

Beck, M.B. (1987). Water quality modelling: a review of uncertainty. Water Resources Research 23 (8): 1393-1442.

Connolly, R.D., Carroll, C., Francis, J., Silburn, D.M., Simpson, B., Freebairn, D.M. (1999). A simulation study of erosion in the Emerald irrigation area. Australian Journal of Soil Research 37: 479 - 494.

Croke, B.F.C and Jakeman, A.J. (2001). Predictions in catchment hydrology: an Australian perspective. Marine Freshwater Research 52: 65 - 79.

De Roo, A.P.J., Jetten, V.G. (1999). Calibrating and validating the LISEM model for two data sets from the Netherlands and South Africa. Catena 37 (3-4): $477-493$.

Department of Land and Water Conservation. (1999). Integrated water quantity-quality model (IQQM) user manual. Department of Land and Water Conservation.

Ecological Cartography of the European Community”. (1977). The CORINE project on soil erosion risk and land quality. https://books.google.com.ng/books.

FAO. (1994). Land degradation in South Asia: Its severity, causes and effects on the people. Available at http://www.fao.org/docrep/v4360e/v4360E04.htm

Futter, M.N., Butterfield, D., Cusby,B.J., Dillon, P.J., Wade, A.J., and Whitehead, P.G.(2007). Modelling the mechanisms that control in-stream dissolved organic carbon dynamics in upland and forested catchments. Water Resour Res., 43: W02424.

Gavrilović, S. (1972). Torrents and Erosion Engineering; Periodical "Izgradnja" - Special Edition, Belgrade (in Serbian).

Hairsine, P.B., Rose, C.W. (1991). Rainfall detachment and deposition: sediment transport in the absence of flow-driven processes. Soil Science Society of America Journal 55 (2): 320 - 324.

Hanley, N., Faichney, R., Munro, A., Shortle, J.S. (1998). Economic and environmental modelling for pollution control in an estuary. Journal of Environmental Management 52: 211 - 225.
Jakeman, A.J., Hornberger, G.M. (1993). How much complexity is warranted in a rainfall-runoff model? Water Resources Research 29 (8): 2637 - 2649.

Kinsell, W.G. (1980). CREAMS: A Field Scale Model for Chemicals, Runoff and Erosion from Agricultural Management Systems. USDA.

Kirkby, M.J,. Jones, R.J.A,. Irvine, B., Gobin, A., Govers, G., Cerdan, O., Van Rompaey, A.J.J., Le Bissonnais., Daruossin, J., King, D., Montanarella., Grimm, M., Vieillefont,V., Puidgdefabregas, J., Boer, M., Kosmas, C.,

Yassoglou, N., Tsara,M., Mantel, S., Van Lynden, G.J and Huting,J. (2004). Pan-European Soil Erosion Risk Assessment: The PESERA Map, version 1 October 2003. EUR 21176. Luxembourg: Office for Official Publications of European Communities.

Laflen, J.M., Lane, L.J., Foster, G.R. (1991). WEPP: A new generation of erosion prediction technology. Journal of Soil and Water Conservation 46: 34 - 38 .

Lane, L.J., Renard, K.G., Foster, G.R., Laflen, J.M. (1992). Development and application of modern soil erosion prediction technology- the USDA experience. Australian Journal of Soil Research 30: $893-912$.

Lane, L., Nicholas, M., Paige, G. (1995). Modelling erosion on hillslopes: concepts, theory and data. In: International congress on modelling and simulation proceedings(Agriculture, catchment hydrology and industry), 1. pp. $1-17$.

Littleboy, M., Cogle, A., Smith, G., Yule, D., Rao, K. (1996). Soil management and production of Alfisols in the semi-arid tropics, I. Modelling the effects of soil management on runoff and soil erosion. Australian Journal of Soil Research 34: 91-102.

Littleboy, M., Silburn, M.D., Freebairn, D.M., Woodruff, D.R., Hammer, G.L., Leslie, J.K. (1992). Impact of soil erosion on production in cropping systems. I. Development and validation of a simulation model. Australian Journal of Soil Research 30: 757 - 774.

Merritt, W.S., Letcher R.A., Jakeman., A.J. (2003). A review of erosion and sediment transport models: Environmental Modelling \& Software 18: 761 - 799.

Misra, R.K., Rose, C.W. (1996). Application and sensitivity analysis of process-based erosion model GUEST. European Journal of Soil Science 47: 593 604.

Moore, I., Gallant, J. (1991). Overview of hydrologic and water quality modelling. In: Moore, I. (Ed.),

AHAMEFULE, HE; FATOLA, FO; OLANIYAN, JO; AMANA, MS; EIFEDIYI, EK; IHEM, E; NWOKOCHA, $C C$; ADEPOJU, AS; ADEPOJU, IO; BABALOLA, MJ 
Modelling the Fate of Chemicals in the Environment. Centre for Resource and Environmental Studies, Australian National University, Canberra, pp. 1-8.

Morgan, R.P.C, Quinton, J.N., Smith, R.E., Govers, G., Poesen, J.W.A., Auerswald, K., Chisci, G., Torri, D., Styczen, M.E., Folly, A.J.V. (1998). The European soil erosion model (EUROSEM): documentation and user guide. Silsoe College, Cranfield University.

Nearing, M.A., Lane, L.J., Lopes, V.L. (1994). Modelling soil erosion. In: Lad, R. (Ed.), Soil Erosion: Research Methods, pp. 127 - 156.

NSERL (1995). WEPP User Summary Version 95.7, National Soil Erosion Research Laboratory Report No. 11.

Oldeman, L.R., Hakkeling, R..A., Sombroek., W.G. (1991). World map of the status of human induced soil degradation.Wageningen, The Netherlands: ISRIC/UNEP.

O'Loughlin, E.M. (1986). Prediction of surface saturation zones in natural catchments by topographic analysis. Water Resources Research 22 (5): 794 - 804.

Pimentel, D., Harvey, C., Resosudarmo, P., Sinclair, K., Kurz, D., McNair, M., Crist, S., Shpritz, L., Fitton, L., Saffouri, R., Blair, R. (1995). Environmental and Economic Costs of Soil Erosion and Conservation Benefits. Science, New Series, 267: 1117-1123.

Post, D. A., Jakeman, A. J. (1999). Predicting the daily streamflow of ungauged catchments in S.E. Australia by regionalising the parameters of a lumped conceptual rainfall-runoff model. Ecological Modelling 123: 94 - 104.

Prosser, I.P., Rustomji, P., Young, B., Moran, C., Hughes, A. (2001). Constructing river basin sediment budgets for the National Land and Water Resources Audit. Technical Report 15/01. CSIRO Land and Water, Canberra.

Prosser, I.P., Rutherford, I.D., Olley, J.M., Young, W.J., Wallbrink, P.J., Moran, C.J. (2001). Large-scale patterns of erosion and sediment transport in river networks, with examples from Australia. Marine and Freshwater Research 52: 81 - 99.

Renard, K.G., Laflen, J.M., Foster, G.R., McCool, D.K. (1994). The revised universal soil loss equation. In: Lal, R. (Ed.), Soil Erosion: Research Methods, pp. $105-126$.

Rose, C.W. (1993). Erosion and sedimentation. In: Bonel, M,Hufschmidt, M.M,. Gladwell, J.S.(Eds).
Hydrology and Water Management in the Humid tropics. Hydrological Research Issues and Strategies for Water Management. Cambridge University Press, pp. $301-343$.

Simons, M., Podger, G., Cooke, R. (1996). IQQM-a hydrologic modelling tool for water resource and salinity management. Environmental Software 11 (1-3).

Vertessey, R.A., Watson, F.G.R., Rahman, J.M., Cuddy, S.D., Seaton, S.P., Chiew, F.H., Scanlon, P.J., Marston, F.M., Lymbuner, L., Jeanelle, S., Verbunt, M. (2001). New software to aid water quality management in the catchments and waterways of the south-east Queensland region. In: Proceedings of the Third Australian Stream Management Conference, August 27-29, pp. $611-616$.

Viney, N.R., Sivapalan, M. (1999). A conceptual model of sediment transport: application to the Avon River Basin in Western Australia. Hydrological Processes 13: $727-743$.

Viney, N.R., Sivapalan, M., Deeley, D. (2000). A conceptual model of nutrient mobilisation and transport applicable at large catchment scales. Journal of Hydrology 240: 23 - 44.

Walton, R., Hunter, H. (1996). Modelling water quality and nutrient fluxes in the Johnstone River Catchment, North Queensland. In: 23rd Hydrology and Resources Symposium, Sydney,http://search.informit.com.au/documentSu mmary; $\mathrm{dn}=364721186621172 ;$ res=ELENG.

Watson, F., Rahman, J., Seaton, S. (2001). Deploying environmental software using the Tarsier modelling framework. In: Proceedings of the Third Australian Stream Management Conference, August 27-29, pp. $631-638$.

Wheater, H.S., Jakeman, A.J., Beven, K.J. (1993). Progress and Directions in Rainfall-runoff Modelling. In: Jakeman, A.J., Beck, M.B., McAleer, M.J. (Eds.), Modelling Change in Environmental Systems. John Wiley and Sons, Chichester, pp. 101 $-132$.

Whitehead, P.G., Wilson, E.J and Butterfield, D. (1998). Semi-distributed intergrated flow and nitrogen model for multiple source assessment in catchments (INCA): Part II- application to large river basins in South Wales and eastern England. Sci. Total Env. $210-211,559-583$.

AHAMEFULE, HE; FATOLA, FO; OLANIYAN, JO; AMANA, MS; EIFEDIYI, EK; IHEM, E; NWOKOCHA, $C C$; ADEPOJU, AS; ADEPOJU, IO; BABALOLA, MJ 